Acta vet. scand. $1969,10,345-358$.

From the Department of Pharmacology and Toxicology, Royal Veterinary and Agricultural University, Copenhagen, Denmark.

\title{
THE EFFECTS OF DIURETICS ON RENAL CLEARANCES IN PIGS*)
}

By

\author{
N. Gyrd-Hansen
}

The effect of diuretics on the electrolyte excretion and renal clearances has been examined previously in man (among others, Heinemann et al. 1959, Heidland et al. 1964), in dogs (among others, Blackmore 1959, Earley et al. 1961, Cassin \& Vogh 1966) and in cows (Knudsen 1960). This paper presents the results of an investigation of the effect of four diuretics in pigs.

\section{MATERIALS AND METHODS}

The experiments were performed on three clinically healthy young female pigs of the Danish Landrace breed, weighing from 37 to $84 \mathrm{~kg}$ at the time of the experiments. From five days before the first experiment and throughout the experimental period, the animals were fed with a commercial fodder mixture, consisting of $75 \%$ barley, $6 \%$ oats, $10 \%$ soya meal, $5 \%$ skimmed milk powder, $3 \%$ meat and bone meal, $0.2 \%$ mixture of vitamins $\mathrm{A}$, $\mathrm{B}, \mathrm{D}$ and $\mathrm{E}$, and $0.8 \%$ mineral salt, consisting of $60 \%$ calcium carbonate, $20 \%$ dicalcium phosphate, $15 \%$ sodium chloride, $3.5 \%$ copper sulphate, $\mathbf{0 . 7 5} \%$ zinc carbonate, $\mathbf{0 . 6 2 5} \%$ manganese oxide and $0.125 \%$ cobalt sulphate. The contents of sodium, potassium and chloride in this fodder were 103, 116 and 115 meq. per $\mathrm{kg}$, respectively. The pigs were weighed once a

*) This work was carried out with financial support from the NOVO Fond. 
week and were given fodder in accordance with their body weight, as follows:

$\begin{array}{lllllllll}\text { Body weight (kg) } & 35 & 40 & 45 & 50 & 60 & 70 & 80 & 90\end{array}$

$\begin{array}{lllllllll}\text { Fodder (kg/day) } & 1.4 & 1.6 & 1.8 & 2.0 & 2.3 & 2.6 & 2.8 & 2.9\end{array}$

During the whole period the pigs were allowed free access to water. The average intake of water was $10 \mathrm{l}$ per day, varying from 7 to 141 per day. 'The concentrations of sodium, potassium and chloride in the drinking water were 1.1, 0.074 and 4.2 meq. per 1 , respectively.

Seventeen experiments were performed with the following diuretics administered intravenously in the doses stated: chlorthiazidum NFN (Salisan $\left.{ }^{\circledR}\right) 2 \mathrm{mg} / \mathrm{kg}$, hydrochlorthiazidum NFN (Esidrex ${ }^{\circledR}$ ) 0.2 and $2 \mathrm{mg} / \mathrm{kg}$, furosemidum NFN (Lasix $®$ ) 0.5 $\mathrm{mg} / \mathrm{kg}$, and mersalylum NFN $(9.2 \%) 2.5$ and $10 \mathrm{mg} / \mathrm{kg}$. The four diuretics were each examined on all three pigs. Where more than one dose of the same diuretic was used, each dose was examined on the three pigs. An exception to this is the large dose of mersalylum which was administered to two pigs only. These experiments were the last that were performed on the pigs in question. There was an interval of at least one week between two experiments on the same pig.

The investigation consisted of simultaneous determination of the clearances of inulin, endogenous creatinine, urea, paraaminohippuric acid (PAH), sodium, potassium and chloride. The experiments were performed on unanaesthetized pigs and commenced with two or three control periods of $20 \mathrm{~min}$. The diuretic to be examined was then injected intravenously in the course of $1-2 \mathrm{~min}$., and immediately afterwards the bladder was emptied. Urine was then collected during five periods of $20 \mathrm{~min}$. In the experiments where mersalylum was used, the urine was collected during seven or eight periods of $30 \mathrm{~min}$.

Inulin and PAH dissolved in $0.6 \%$ sodium chloride were infused at a rate of $3 \mathrm{ml}$ per min. The amounts of inulin and PAH used and the clearance technique have been described in detail by Gyrd-Hansen (1968).

The pigs were killed, bled and dissected on the day after the last clearance experiment. The kidneys were weighed and examined macroscopically and microscopically. 


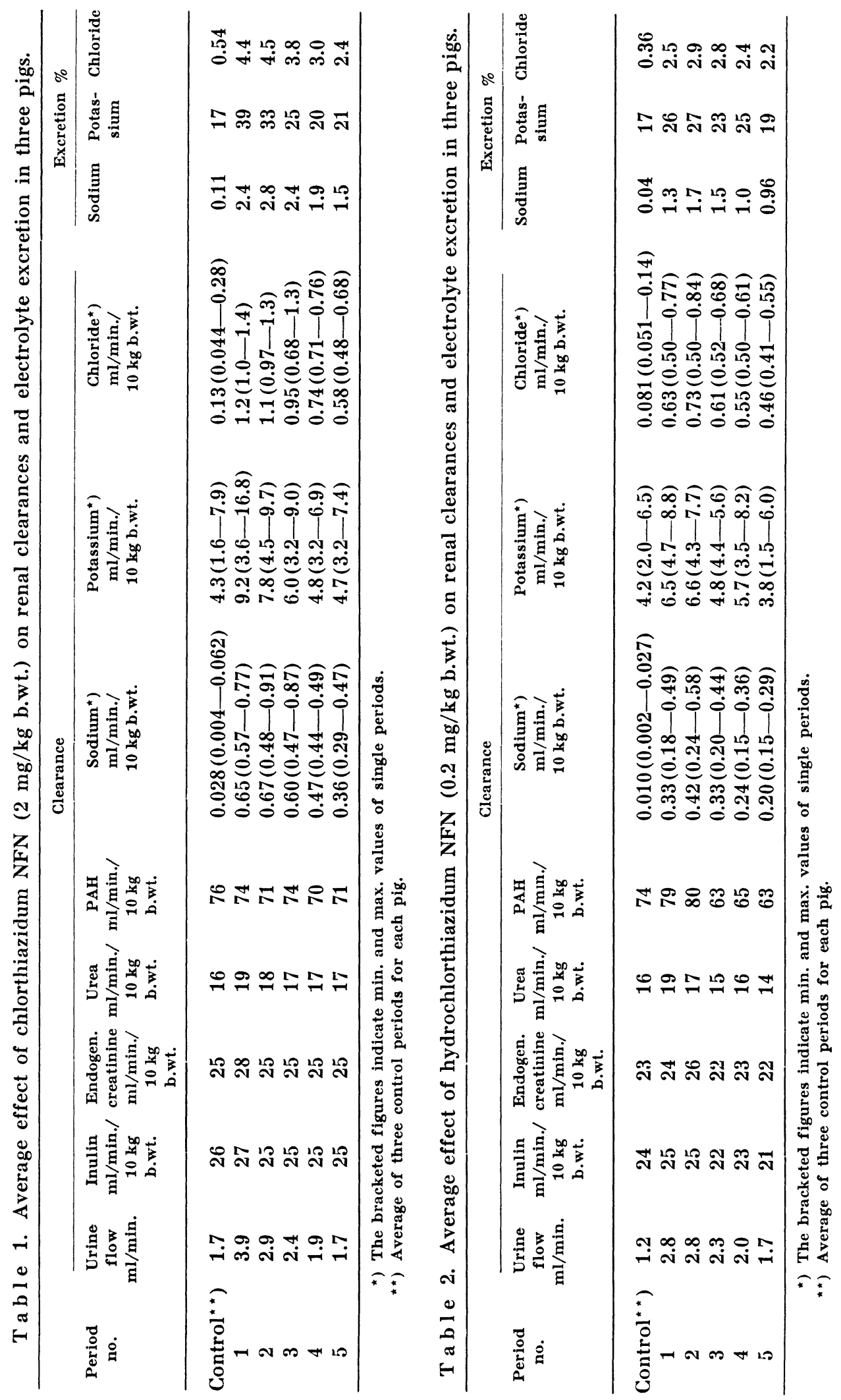


The analytical methods used were as follows:

Inulin: Brun (1946), endogenous creatinine: Bonsnes \& Taussky (1945), PAH: Bratton \& Marshall (1939), urea: Conway (1950), chloride: Schales \& Schales (1941). Sodium and potassium were determined by flame photometer (Beckman Direct Reading Flame Photometer). All the plasma concentrations found were calculated to correspond to the values at the water phase of the plasma, the content of dry matter in plasma being considered to be $8 \%$. The haematocrit values were determined in microhaematocrit tubes after centrifugation in an MSE Micro Haematocrit Centrifuge for $15 \mathrm{~min}$. at 4500 r.p.m.

The urine specimens were examined for glucose and protein by means of Ames Clinistix ${ }^{\circledR}$ and Albustix $\AA$, respectively.

\section{RESULTS}

Table 1 shows the effect on the urine flow and renal clearances of $2 \mathrm{mg} / \mathrm{kg}$ chlorthiazidum NFN. The results are given as the average for the experiments on the three pigs, and it will be seen that the clearances of inulin, $\mathrm{PAH}$, endogenous creatinine and urea were almost constant throughout the whole experiment. The excretion of sodium and chloride, however, was 20 and 8 fold increased even as early as the first period. The effect of chlorthiazidum on the sodium and chloride excretion was greatest in the first and second periods but could still be seen during all five periods. In the last period this excretion was about 12 and 4 times, respectively, greater than in the control periods. Both the urine flow and potassium excretion were greatest in the first period when both values were about twice as high as in the control periods. In the fourth and fifth periods the urine flow and potassium excretion decreased to the original size.

The effect of 0.2 and $2 \mathrm{mg} / \mathrm{kg}$ hydrochlorthiazidum NFN is shown in Tables 2 and 3. It will be seen that there was no influence on the clearances of inulin, endogenous creatinine and PAH, while the urea clearance was affected slightly with $2 \mathrm{mg} /$ kg. With both doses the urine flow was greatest in the first period, and throughout all five periods it was higher than in the control periods. The effect on the excretion of sodium and chloride was immediate and reached its maximum in the second period. With the larger dose, the increased excretion of sodium and chloride was almost unchanged throughout the whole ob- 


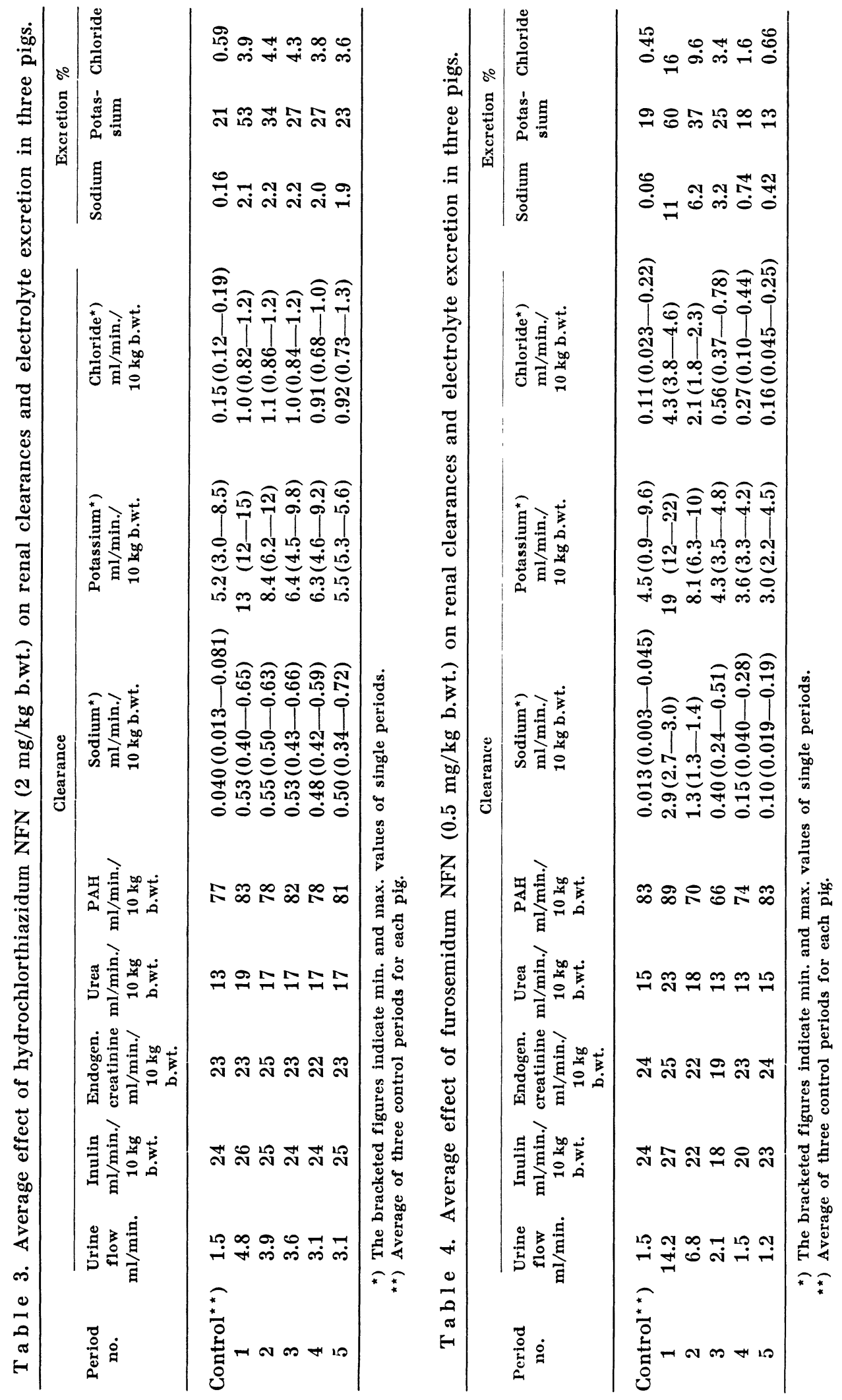


servation period, while with the low dose the excretion of these substances decreased gradually after the second period. With both doses the potassium excretion was greatest in the first and second periods, and the value in the fifth period was down to the same as in the control periods.

Table 4 shows the effect of $0.5 \mathrm{mg} / \mathrm{kg}$ furosemidum NFN on the urine flow and renal clearances. As will be seen, there was an almost tenfold increase in urine flow during the first period in comparison with the control periods. In the second and third periods it decreased strongly and by the last period it was the same as in the control periods. The clearances of inulin, endogenous creatinine, urea and $\mathrm{PAH}$ were somewhat higher in the first period, and during the following three periods they were a little lower than in the control periods. In the fifth period the clearances were the same as they were originally. The excretion of sodium, potassium and chloride was greatest in the first period and was 200, 3 and 40 times, respectively, greater than in the control periods. However, the electrolyte excretion fell rapidly, and in the fifth period the values for potassium and chloride were of the same order of magnitude as in the control periods, while the excretion of sodium was still somewhat increased.

The results of the experiments with mersalylum NFN (2.5 $\mathrm{mg} / \mathrm{kg}$ ) are shown in Table 5. It will be seen that the urine flow was greatest in the second period, after which it fell gradually and by the eighth period was of the same size as in the control periods. There were no marked changes in the clearances of inulin, endogenous creatinine, urea and PAH. The excretion of sodium and chloride was slightly increased in the first period and reached its maximum in the second and third periods, where the values were 70 and 15 times, respectively, higher than in the control periods. The excretion of potassium did not increase until the second period and was greatest in the fifth period. In the eighth period, or about four hours after the administration of mersalylum, the excretion of sodium and chloride was still slightly increased, while the excretion of potassium had reached its original level.

Table 6 shows the effect of mersalylum NFN when given in a dose of $10 \mathrm{mg} / \mathrm{kg}$. The urine flow increased steadily and reached $13.5 \mathrm{ml} / \mathrm{min}$. in the third period, after which it fell again and by the seventh period had returned to the control level. The 


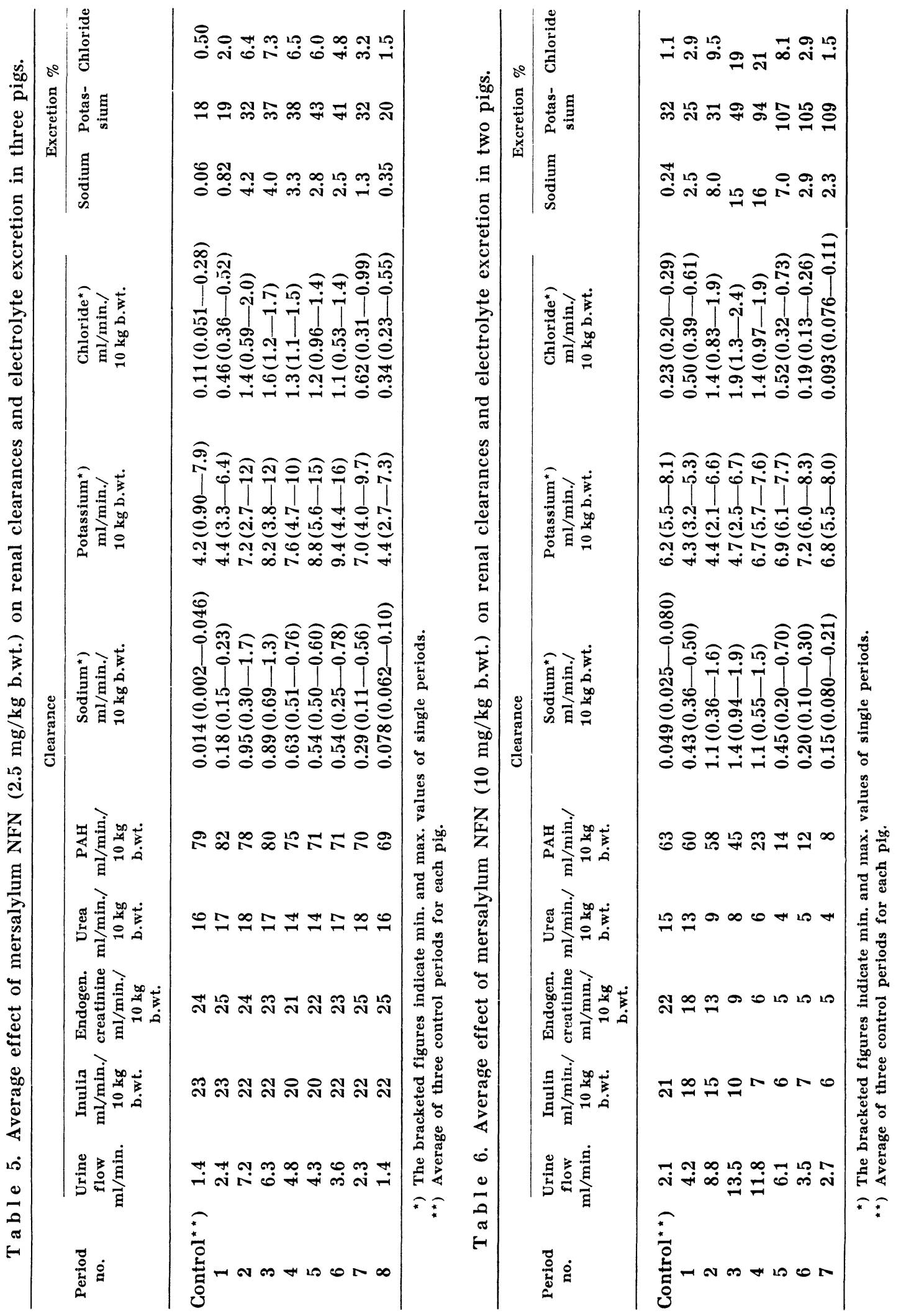


clearances of inulin, endogenous creatinine and urea fell from the first to the fifth period and in that and the last two periods were $20-30 \%$ of the corresponding clearances in the control periods. The PAH clearance decreased steadily during the whole experiment and in the seventh period it was about $13 \%$ of the original value. It will be seen that the clearance of PAH during the last periods was of the same size as the filtration clearance. The concentration in plasma of creatinine and urea inrceased during the experiments from 13 and $300 \mu \mathrm{g} / \mathrm{ml}$ to 24 and 390 $\mu \mathrm{g} / \mathrm{ml}$, respectively. The excretion of sodium and chloride increased steadily and was greatest in the third period, by which time it was 20 and 7 times, respectively, greater than in the control periods. During the last four periods the excretion decreased gradually and in the seventh period it was $3-4$ times its original size. The excretion of potassium was somewhat decreased in the first three periods, while it became slightly increased in the last four periods. On account of the reduced inulin clearance, the excretion percentage $^{\star}$ ) of the three electrolytes were very high. Urine from the last five periods gave a clear positive reaction for protein and a very strong reaction for glucose.

The concentrations of sodium, potassium and chloride in plasma were constant throughout all the experiments and showed average values of $146 \mathrm{meq} / \mathrm{l}(133-159), 4.2 \mathrm{meq} / \mathrm{l}$ (3.3-5.1) and $109 \mathrm{meq} / \mathrm{l}(105-112)$, respectively. The haematocrit values in the individual experiments were either constant or slightly decreased, all values lying between 32 and 48. Except for the experiment with $10 \mathrm{mg} / \mathrm{kg}$ mersalylum, none of the urine specimens contained protein or glucose.

\section{Necropsy}

The kidneys of the two pigs used in the experiment with 10 $\mathrm{mg} / \mathrm{kg}$ mersalylum were slightly enlarged, and were greyishbrown with numerous small, densely-packed lighter spots. The kidneys of the third pig showed no pathological changes, and the same was the case with the other organs from all three pigs.

Microscopy of the kidneys from the pigs that had been given the large dose of mersalylum revealed diffuse tubular degene-

*) Excretion percentage of an electrolyte:

Clearance of the electrolyte $\times 100$

Clearance of inulin 
ration with necrosis here and there in the proximal tubules and slight tubular degeneration in the distal tubules. In the lumen of the tubules and the collecting tubules there were numerous hyaline and albumin cylinders. Nothing abnormal was found on microscopy of the kidneys of the third pig that had been given only $2.5 \mathrm{mg} / \mathrm{kg}$ mersalylum.

\section{DISCUSSION}

The clearances and excretion percentages found in the control periods correspond to those found by Gyrd-Hansen (1968) in his normal pigs.

The experiments with chlorthiazidum show that in pigs this diuretic in the dose used increased considerably the excretion of sodium and chloride, while the values for potassium and water excretion were only moderately increased. In contrast, neither the clearances of inulin, endogenous creatinine, urea nor PAH were affected to any degree. The fact that the glomerular filtration (GFR) was not affected by chlorthiazidum has been observed previously in man (Laragh et al. 1958), in dogs (Beyer $\&$ Baer 1959) and in cows (Knudsen 1960). However, there is not complete agreement regarding this matter, since Blackmore (1959) and Earley et ai. (1961) observed a marked decrease in the GFR of dogs after the administration of chlorthiazidum. Heinemann et al. (1959) observed the same phenomenon in man. The increase in the excretion of sodium, potassium and chloride found in the first and second periods in pigs corresponds to the findings of Blackmore in dogs after the intravenous administration of $2.5 \mathrm{mg} / \mathrm{kg}$ chlorthiazidum. Using intravenous injection of $500 \mathrm{mg}$ chlorthiazidum, Heinemann et al. found that the excretion of sodium and chloride in man was increased 6-12 and 4-10 times, respectively.

As with chlorthiazidum, hydrochlorthiazidum had no effect on the clearances of inulin, endogenous creatinine or PAH in pigs. Cassin \& Vogh (1966) showed that in dogs $5 \mathrm{mg} / \mathrm{kg}$ hydrochlorthiazidum administered intravenously did not change the creatinine and PAH clearances. The effect of $2 \mathrm{mg} / \mathrm{kg}$ hydrochlorthiazidum on the excretion of sodium and chloride in pigs corresponds to that found with the same dose of chlorthiazidum, though hydrochlorthiazidum seemed to have a more prolonged effect than chlorthiazidum. The effect of the low dose of hydro- 
chlorthiazidum $(0.2 \mathrm{mg} / \mathrm{kg})$ on the excretion of sodium and chloride was about $2 / 3$ of the effect of chlorthiazidum $(2 \mathrm{mg} / \mathrm{kg})$. Beyer \& Baer (1961) and Barret et al. (1959) examined the influence of chlorthiazidum and hydrochlorthiazidum on the electrolyte excretion in dogs, and found that the maximum saluretic effect was almost identical for the two diuretics. On the other hand, lower doses of hydrochlorthiazidum had a 6-8 times greater effect than chlorthiazidum. The increase in urine flow and excretion of potassium provoked by $2 \mathrm{mg} / \mathrm{kg}$ hydrochlorthiazidum in pigs corresponds to what Beyer $\mathcal{K}$ Baer (1959) found after intravenous administration of $1.25 \mathrm{mg} / \mathrm{kg}$ hydrochlorthiazidum into dogs.

The experiment with furosemidum shows that this diuretic caused a very great increase both in urine flow and in the excretion of sodium and chloride, while the potassium excretion was only moderately increased. At the same time, there was a fluctuation in the clearances of inulin, endogenous creatinine, urea and PAH. Corresponding changes in the inulin and $\mathrm{PAH}$ clearances following intravenous administration of furosemidum have been seen in man (Heidland et al. 1964) and in the inulin clearance in dogs (Suki et al. 1965). The reason for this may be a flushing phenomenon caused by the rapid changes in the amount of urine flow, since Suki et al. found that the inulin clearance remained constant if the dogs had been subjected to water loading and consequently already had high urine flow. However, Ludens et al. (1968) found that $1 \mathrm{mg} / \mathrm{kg}$ furosemidum administered intravenously to dogs caused a $50 \%$ increase in the renal blood flow, while the inulin clearance remained unchanged. Furosemidum increased the excretion of sodium and chloride much more strongly than chlorthiazidum and hydrochlorthiazidum, but, on the other hand, the duration of the effect was very short. However, the increase in the potassium excretion was of the same order of magnitude for all three diuretics.

A dose of $2.5 \mathrm{mg} / \mathrm{kg}$ mersalylum had no effect on the inulin, endogenous creatinine, urea or PAH clearances in pigs. Correspondingly, it has been found that the inulin, urea and diodrast clearances were unchanged in man when a similar dose of mersalylum was given (Brun et al. 1947). Blackmore found that intravenous administration of $2.5 \mathrm{mg} / \mathrm{kg}$ mersalylum into dogs followed by continuous infusion did not affect the glomerular 
filtration. The influence of mersalylum on the sodium, chloride and water excretion in pigs was more prolonged than that of chlorthiazidum and hydrochlorthiazidum. This phenomenon has also been observed in dogs (Blackmore), and in cows (Knudsen). The moderate and delayed increase in potassium excretion caused by mersalylum corresponds to what Blackmore found in dogs. However, in cows Knudsen demonstrated that the potassium excretion was not affected by mersalylum.

When the dose of mersalylum was increased to $10 \mathrm{mg} / \mathrm{kg}$ in pigs there was a toxic effect on the kidneys resulting in a reduction of both the glomerular filtration and the tubular secretion. In cows, Knudsen observed an almost corresponding decrease in the creatinine clearance after intravenous administration of $5 \mathrm{mg} / \mathrm{kg}$. However, dogs seem to be less sensitive to diuretics containing mercury. Duggan \& Pitts (1950) injected $15 \mathrm{mg}$ mercuhydrine/ $\mathrm{kg}$ intravenously into dogs without noting any fall in the glomerular filtration. As far as the content of mercury is concerned, $15 \mathrm{mg}$ mercuhydrine corresponds to $\mathbf{1 1 . 5}$ mg mersalylum. Tubular damage was shown by a very sharp fall in the PAH clearance and during the last collection periods by the presence of considerable amounts of glucose in the urine. Both the secretion of $\mathrm{PAH}$ and the reabsorption of glucose take place in the proximal tubules i.e. in the section of the tubules where the most severe histological changes were found. In his experiments on cows, Knudsen also found pronounced degeneration in the proximal tubules.

\section{REFERENCES}

Barret, W. E., R. A. Rutledge, H. Sheppard \& A. J. Plummer: The pharmacology of hydrochlorothiazide (EsidrexTM), a new orally effective sulfonamide diuretic. Toxicol. appl. Pharmacol. 1959, 1, 333-349.

Beyer, K. H. \& J. E. Baer: The pharmacology of chlorothiazide and its analogues. Int. Rec. Med. 1959, 172, 413-426.

Beyer, K. H. \& J. E. Baer: Physiological basis for the action of newer diuretic agents. Pharmacol. Rev. 1961, 13, 517-562.

Blackmore, W. P.: Comparative effects of chlorothiazide and mersalyl (mersalyl sodium and theophylline) on the kidney. J. Pharmacol. exp. Ther. 1959, 125, 303-308.

Bonsnes, R. W. \& H. H. Taussky: On the colorimetric determination of creatinine by the Jaffe reaction. J. biol. Chem. 1945, 158, $581-591$. 
Bratton, A. C. \& E. K. Marshall: A new coupling component for sulfanilamide determination. J. biol. Chem. 1939, 128, 537-550.

Brun, C.: In Iversen, P., T. Bjering \& J. Bing: De medicinske nyrelidelser. (Medical renal disease). 2nd Ed., København 1946, pp. 83-85.

Brun, C., T. Hilden \& F. Raaschou: On the effect of mersalyl on the renal function. Acta pharmacol. (Kbh.) 1947, 3, 1-12.

Cassin, S. \& B. Vogh: Effect of hydrochlorthiazide on renal blood flow and clearance of para-aminohippurate and creatinine. Proc. Soc. exp. Biol. (N.Y.) 1966, 122, 970-973.

Conway, E. J.: Microdiffusion analysis and volumetric error. 3rd Ed., London 1950, p. 152.

Duggan, J. J. \& R. F. Pitts: Studies on diuretics. I. The site of action of mercurial diuretics. J. clin. Invest. 1950, 29, 365-371.

Earley, L. E., M. Kahn \& J. Orloff: The effects of infusions of chlorothiazide on urinary dilution and concentration in the dog. J. clin. Invest. 1961, 40, 857-866.

Gyrd-Hansen, N.: Renal clearances in pigs. Acta vet. scand. 1968, 9, $183-198$.

Heidland, A., K. Klütsch \& F. Suzuki: Nierenhämodynamik, Wasserund Elektrolytausscheidung nach 4-Chlor-N-(2-furylmethyl)-5sulfamoyl-anthranilsäure. (Renal haemodynamics, water and electrolyte elimination after 4-Chloro-N-(2-furylmethyl)-5-sulfamoyl-anthranilic acid). Arzneimittel-Forsch. 1964, 14, 713-716.

Heinemann, H. O., F. E. Demartini \& J. H. Laragh: The effect of chlorothiazide on renal excretion of electrolytes and free water. Amer. J. Med. 1959, 26, 853-861.

Knudsen, E.: Electrolyte excretion in the cow, as influenced by variations in the urine flow. Acta vet. scand. 1960, 1, 305-323.

Laragh, J. H., H. O. Heinemann \& F. E. Demartini: Effect of chlorothiazide on electrolyte transport in man. J. Amer. med. Ass. $1958,166,145-152$.

Ludens, J. H., J. B. Hook, M. J. Brody \& H. E. Williamson: Enhancement of renal blood flow by furosemide. J. Pharmacol. exp. Ther. 1968, 163, 456-460.

Schales, O. \& S. S. Schales: A simple and accurate method for the determination of chloride in biological fluids. J. biol. Chem. $1941,140,879-884$.

Suki, W., F. C. Rector, Jr. \& D. W. Seldin: The site of action of furosemide and other sulfonamide diuretics in the dog. J. clin. Invest. 1965, 44, 1458-1469.

\section{SUMMARY}

The following diuretics have been examined for their influence on renal clearances in pigs: chlorthiazidum $(2 \mathrm{mg} / \mathrm{kg})$, hydrochlorthiazidum $(0.2$ and $2 \mathrm{mg} / \mathrm{kg})$, furosemidum $(0.5 \mathrm{mg} / \mathrm{kg})$ and mersalylum (2.5 and $10 \mathrm{mg} / \mathrm{kg})$. The investigation comprised determi- 
nation of the clearances of inulin, endogenous creatinine, urea, PAH, sodium, potassium and chloride, before and after the administration of the diuretics.

Chlorthiazidum, hydrochlorthiazidum and mersalylum in the low dose did not affect the clearances of inulin, endogenous creatinine, urea and PAH. When furosemidum was administered, there was first a slight increase and then a decrease in those clearances. After administration of $10 \mathrm{mg} / \mathrm{kg}$ mersalylum, there was a strong decrease in the inulin, endogenous creatinine, urea and PAH clearances, and simultaneously glucose and protein could be found in the urine.

All four diuretics caused a markedly increased excretion of sodium and chloride, while the excretion of potassium was only moderately increased. The effect on the excretion of sodium and chloride was of about the same order of magnitude for chlorthiazidum and hydrochlorthiazidum, though the effect of the latter was slightly more prolonged. In contrast to those two diuretics, furosemidum had a very strong but short effect. The influence of mersalylum on the excretion of sodium and chloride was somewhat stronger and more prolonged than that of the thiazides. Histological examinations of the kidneys of the pigs given $10 \mathrm{mg} / \mathrm{kg}$ mersalylum revealed pronounced tubular degeneration, particularly in the proximal tubules.

\section{ZUSAMMENFASSUNG \\ Die Wirkung verschiedener Diuretika auf die renale Clearance bei Schweinen.}

Die Wirkung auf die renale Clearance bei Schweinen ist mit folgenden Diuretika vorgenommen worden: Chlorthiazidum $(2 \mathrm{mg} /$ $\mathrm{kg})$, Hydrochlorthiazidum $(0,2$ und $2 \mathrm{mg} / \mathrm{kg})$, Furosemidum $(0,5$ $\mathrm{mg} / \mathrm{kg}$ ) und Mersalylum (2,5 und $10 \mathrm{mg} / \mathrm{kg})$. Die Untersuchungen umfassten Bestimmungen der Clearance für Inulin, endogenes Kreatinin, Harnstoff, PAH, Natrium, Kalium und Chlorid vor und nach intravenöser Eingabe eines Diuretikum.

Chlorthiazidum, Hydrochlorthiazidum sowie Mersalylum in der kleinen Menge beeinflussen nicht die Clearance für Inulin, endogenes Kreatinin, Harnstoff und PAH. Nach Eingabe von Furosemidum wird zuerst eine Steigerung und anschliessend ein Fall in der erwähnten Clearancen beobachtet. Nach Eingabe von $10 \mathrm{mg} / \mathrm{kg}$ Mersalylum sieht man einen starken Fall in der Clearance für Inulin, endogenes Kreatinin, Harnstoff und PAH und gleichzeitig wird Glukose und Protein im Harn festgestellt.

Alle vier Diuretika verursachen eine stark erhöhte Ausscheidung von Natrium und Chlorid, während die Ausscheidung von Kalium nur moderat erhöht wird. Die Wirkung von Chlorthiazidum und Hydrochlorthiazidum auf die Ausscheidung von Natrium und Chlorid ist von entsprechender Grössenordnung; die Wirkung von Hydrochlorthiazidum hält jedoch etwas länger an. Im Verhältnis zu diesen beiden Diuretika hat Furosemidum einer sehr kräftige aber kurzfristige Wirkung. Die Wirkung von Mersalylum auf die Natrium- 
und Chloridausscheidung ist etwas stärker und etwas andauernder als die der Thiaziden. Bei der histologischen Untersuchung der Nieren von den Ferkeln, denen $10 \mathrm{mg} / \mathrm{kg}$ Mersalylum verabreicht war, wurde eine ausgesprochene tubulare Degeneration besonders in den proximalen Tubuli festgestellt.

\section{SAMMENDRAG}

Diuretikas virkning på renale clearances hos svin.

Virkningen på de renale clearances hos svin er unders $\varnothing$ gt for følgende diuretika: chlorthiazidum $(2 \mathrm{mg} / \mathrm{kg})$, hydrochlorthiazidum $(0,2 \mathrm{og} 2 \mathrm{mg} / \mathrm{kg})$, furosemidum $(0,5 \mathrm{mg} / \mathrm{kg})$ og mersalylum $(2,5 \mathrm{og}$ $10 \mathrm{mg} / \mathrm{kg})$. Unders $\varnothing$ gelserne omfatter bestemmelse af clearance for inulin, endogen kreatinin, urinstof, PAH, natrium, kalium og klorid f $\varnothing \mathbf{r}$ og efter intraven $\varnothing s$ indgift af diuretikum.

Chlorthiazidum, hydrochlorthiazidum samt mersalylum i den lave dosis påvirker ikke clearance for inulin, endogen kreatinin, urinstof og PAH. Ved indgift af furosemidum ses først en stigning og derpå et fald i de næunte clearances. Efter indgift af $10 \mathrm{mg} / \mathrm{kg}$ mersalylum iagttages et stærkt fald i clearance for inulin, endogen kreatinin, urinstof og PAH samtidig med, at der optræder glukose og protein i urinen.

Alle fire diuretika fremkalder en stærkt $\emptyset$ get udskillelse af natrium og klorid, mens udskillelsen af kalium фges moderat. Virkningen på udskillelsen af natrium og klorid er for chlorthiazidum og hydrochlorthiazidum af samme st $\varnothing$ rrelsesorden; hydrochlorthiazidum har dog en lidt mere langvarig virkning. I forhold til disse to diuretika har furosemidum en meget kraftig, men kortvarig virkning. Mersalylums virkning på natrium- og kloridudskillelsen er noget kraftigere og mere langvarig end thiazidernes. Ved den histologiske unders $\varnothing$ gelse af nyrerne fra de grise, der havde fået indgivet $10 \mathrm{mg} / \mathrm{kg}$ mersalylum, konstateredes en udtalt tubulær degeneration specielt $i$ de proximale tubuli.

(Received March 4, 1969). 